Orthopäde $2021 \cdot 50: 188-197$

https://doi.org/10.1007/s00132-020-03922-8

Published online: 18 May 2020 (c) The Author(s) 2020

Dirk Zajonz ${ }^{1,2,3} \cdot$ Alexandros Daikos $^{1,3} \cdot$ Florian Prager $^{1} \cdot$ Melanie Edel $^{1,2}$. Robert Möbius ${ }^{1,2} \cdot$ Johannes K. M. Fakler' $\cdot$ Andreas Roth ${ }^{1,2} \cdot$ Mohamed Ghanem $^{1}$ 'Department of Orthopaedics, Traumatology and Plastic Surgery, University Hospital Leipzig, Leipzig, Germany

${ }^{2}$ ZESBO, Center for Research on Musculoskeletal Systems, University of Leipzig, Leipzig, Germany ${ }^{3}$ Clinic for Orthopaedics, Traumatology and Reconstructive Surgery, Zeisigwald Hospitals BETHANIEN Chemnitz, Chemnitz, Germany

\section{Significance of nutritional status in the development of periprosthetic infections}

\section{A retrospective analysis of 194 patients}

\section{Introduction}

Despite the enormous progress in surgical treatment for reducing the risk of infections, periprosthetic joint infections (PJI) remain a major challenge and risk for the affected patients, the health system, and attending personnel [1-4]. Considering the grave effects of PJI on patients and the society, the optimization of patient-related risk factors is vital [4]. The effects of nutritional status and protein balance are considered to be significant prognostic factors for the development of PJI [5, 6]. Malnutrition is reported to be associated with complications, which range from prolonged hospital stay to impaired wound healing, after the hip and knee endoprosthesis implantation [5, 7-11]; however, this association seems to receive too little attention in current clinical practice. Jensen et al. reported that $50 \%$ of the patients who received elective total hip arthroplasty (THA) already had a clinical or subclinical nutrient deficiency before surgery [12]. The increasing supernutrition and the growing number of obese persons in industrial countries, which have caused an increase in metabolic diseases, support this finding. In con-

The data sets used and/or analyzed during this study are available from the corresponding author on reasonable request.

The authors D. Zajonz and A. Daikos contributed equally to the manuscript. trast, Kaidar-Person et al. reported that obese persons can also be malnourished because their diets are often low in vitaparticular, low serum albumin level and protein deficiency are reportedly negative predictive factors with respect to the rates for perioperative and postoperative complications, such as PJI, associated with primary joint endoprostheses [15, 16]. Accordingly, a seven-fold increased risk of arthroplasty-related infections was observed at a preoperative albumin level of <35 g/L [9]; however, proteins are essential for adequate wound healing and serve as carriers for most vitamins (such as vitamin D and its metabolites), hormones, and mediators. The importance of vitamin D in orthopedic infections and particularly in septic disease progression has been proven [17-20]. It is also known that $99 \%$ of the vitamin $\mathrm{D}$ present in the human body exists in a protein-bound form (e.g. vitamin D-binding protein and albumin) and that it is fully effective only when the protein level is balanced $[21,22]$. It is striking that none of the cited studies took the importance of the nutritional status, particularly the protein balance, into account.

This retrospective analysis aimed to examine the nutritional status of and the protein balance in patients with periprosthetic hip and knee joint infections. Patients with primary endoprosthesis immins, proteins, and nutrients [13, 14]. In plantation and aseptic loosening constituted the comparison groups.

\section{Material and methods}

This study was approved by the ethics committee of the University of Leipzig (approval number: 025-16-01022016). The study was designed and the required sample size was estimated in advance using a power analysis program $\left(\mathrm{G}^{\star}\right.$ Power; version 3.1.9.2., Axel Buchner, Edgar Erdfelder, Franz Faul, Albert-Georg

\begin{tabular}{|ll}
\hline \multicolumn{2}{|l}{ Abbreviations } \\
\hline$B M I$ & Body mass index \\
\hline CGI & Control group I \\
\hline CG II & Control group II \\
\hline$C R P$ & C-reactive protein \\
\hline$H b A 1 C$ & Glycated hemoglobin \\
\hline$H D L$ & High-density lipoprotein \\
\hline$I C M P J I$ & $\begin{array}{l}\text { International consensus meeting } \\
\text { on periprosthetic joint infection }\end{array}$ \\
\hline$L D L$ & Low-density lipoprotein \\
\hline$N R S$ & Nutritional risk screening \\
\hline$P J I$ & Periprosthetic joint infection \\
\hline$S D$ & Standard deviation \\
\hline$S G$ & Study group \\
\hline$T H A$ & Total hip arthroplasty \\
\hline$T K A$ & Total knee arthroplasty \\
\hline
\end{tabular}


Hier steht eine Anzeige.

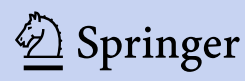


Table 1 Comparison of the examination groups separated into acute and low-grade PJI with respect to laboratory tests

\begin{tabular}{|c|c|c|c|}
\hline & Acute infection & Low-grade infection & $p$-value \\
\hline $\begin{array}{l}\text { Number of subjects } \\
\text { (excluded antiosteoporotic treated patients) }\end{array}$ & $26.2 \%(16 / 61)$ & $73.8 \%(45 / 61)$ & - \\
\hline Hemoglobin in mmol/l (7.2-10.0) & $5.3 \pm 1.53$ & $6.5 \pm 1.34$ & 0.015 \\
\hline Leukocytes in $10^{9} / \mathrm{I}(3.5-9.8)$ & $11.4 \pm 4.3$ & $7.6 \pm 1.4$ & $<0.001$ \\
\hline C-reactive protein in $\mathrm{mg} / \mathrm{l}(<5)$ & $176.3 \pm 64$ & $27.3 \pm 54$ & $<0.001$ \\
\hline Albumin in $\mathrm{g} / \mathrm{l}(35-52)$ & $28.0 \pm 7.1$ & $37.7 \pm 5.5$ & 0.030 \\
\hline Patients with lowered albumin values in $\%$ & $80.0 \%(12 / 15)$ & $36.4 \%(16 / 44)$ & $<0.001$ \\
\hline Serum protein in g/l (63-83) & $59 \pm 7.12$ & $69.3 \pm 6.32$ & 0.040 \\
\hline Patients with lowered serum protein values in $\%$ & $86.7 \%(13 / 15)$ & $22.7 \%(10 / 44)$ & $<0.001$ \\
\hline Creatinine in $\mu \mathrm{mol} / \mathrm{l}(45-84)$ & $75 \pm 36.1$ & $77 \pm 21.9$ & 0.390 \\
\hline Alanine aminotransferase in $\mu \mathrm{kat} / \mathrm{l}(0.17-0.58)$ & $0.33 \pm 0.13$ & $0.32 \pm 0.13$ & 0.700 \\
\hline \multicolumn{4}{|c|}{$\begin{array}{l}\text { Pathological values are highlighted in italics } \\
\text { Statistically significant values are highlighted in bold } \\
\text { Values are expressed as median ( } \pm \text { mean deviation) or as percentage (absolute/total) } \\
\text { Standard values or the physiological range are given in brackets }\end{array}$} \\
\hline
\end{tabular}

Table 2 Comparison of the examination groups (SG, CG I primary arthroplasty, CG II aseptic revision) with respect to the number of subjects, median age (min-max), number (absolute, \%) of male subjects, THA or TKA BMI and NRS 2002

\begin{tabular}{|c|c|c|c|c|c|}
\hline & SG & CG I & $\begin{array}{l}p \text {-value } \\
\text { (SG vs. CG I) }\end{array}$ & CG II & $\begin{array}{l}p \text {-value } \\
\text { (SG vs. CG II) }\end{array}$ \\
\hline \multicolumn{6}{|l|}{ General group characteristics } \\
\hline Number of subjects & 61 & 78 & - & 55 & - \\
\hline Median age in years (min-max) & $74(35-88)$ & $68(46-87)$ & 0.125 & $67(21-84)$ & 0.239 \\
\hline Number of male patients (\%) & $35(57.4)$ & $39(50.0)$ & 0.387 & $18(32.7)$ & 0.008 \\
\hline Number of THA (\%) & $32(52.5)$ & $48(61.5)$ & \multirow[t]{2}{*}{0.282} & $28(50.9)$ & \multirow[t]{2}{*}{0.868} \\
\hline Number of TKA (\%) & $29(47.5)$ & $30(38.5)$ & & $27(49.1)$ & \\
\hline Median BMl in kg/m² (SD) & $27.8(5.8)$ & $28.6(5.6)$ & 0.337 & $28.7(4.8)$ & 0.652 \\
\hline $\begin{array}{l}\text { Median nutritional risk screening (NRS 2002) score } \\
\text { (SD) }\end{array}$ & $1.0(0.9)$ & $0.0(0.7)$ & $<0.001$ & $1.0(0.7)$ & - \\
\hline $\begin{array}{l}\text { Patients with critical nutritional status (NRS } \geq 3 \text { ) in } \\
\%\end{array}$ & $8.2(5 / 61)$ & $1.3(1 / 78)$ & n.a. & $0.0(0 / 55)$ & n.a. \\
\hline
\end{tabular}

Lang, Department of Psychology, Heinrich-Heine-University Düsseldorf, Germany). An effect size of medium value $(\mathrm{d}=0.5)$ and a statistical test power of $80 \%(1-\beta=0.8)$ were assumed for detecting significant differences $(\alpha=0.05)$.

This study was conducted at a university maximum care hospital in Europe and involved an analysis with patients of German nationality. The inclusion criteria for the study group (SG) were the presence of periprosthetic hip or knee joint infection, written consent for participation, and minimum age of 18 years. In the present study, periprosthetic infection was defined based on the criteria of the International Consensus Meeting on Periprosthetic Joint Infection (ICMPJI),
2013 [23, 24]. Patients with primary endoprosthesis implantation and revision surgery due to aseptic loosening served as the control groups I (CG I) and II (CG II), respectively. According to the matching procedure both the CGI and II were adapted to the SG with respect to age, body mass index (BMI), and implant location (THA or total knee arthroplasty, TKA). Aseptic loosening was defined as radiologically determined implant loosening with appropriate symptoms.

From 1 January 2015 to 29 September 2017, a total of 61 patients were included in the SG with $16 / 61$ (26.2\%) acute PJI and 45/61 (73.8\%) low-grade PJI. Detailed information is given in • Table 1. Acquisition of suitable patients for CGI and II ( $\mathrm{n}_{\mathrm{CG}}=78$ and $\left.\mathrm{n}_{\mathrm{CG}} \mathrm{II}=55\right)$ was started at the same time but lasted until 3 November 2017. Total cholesterol, high-density lipoprotein (HDL) cholesterol, low-density lipoprotein (LDL) cholesterol, albumin, C-reactive protein (CRP), hemoglobin, creatinine, and alanine aminotransferase levels as well as total protein in serum of all patients were determined via analysis of peripheral venous blood samples; all these levels were ascertained during inpatient admission prior to surgery. Furthermore, all patients completed a nutrition questionnaire comprising questions regarding eating habits, sports activities, and weight fluctuations. The nutritional risk screening (NRS) 2002 score and 
Orthopäde 2021 · 50:188-197 https://doi.org/10.1007/s00132-020-03922-8

(c) The Author(s) 2020

D. Zajonz · A. Daikos · F. Prager · M. Edel · R. Möbius · J. K. M. Fakler · A. Roth · M. Ghanem

\section{Significance of nutritional status in the development of periprosthetic infections. A retrospective analysis of 194 patients}

\section{Abstract}

Background. Malnutrition caused by protein and vitamin deficiencies is a significant negative prognostic factor in surgical wound healing disorders and infections. Particularly in elective surgery, preoperative compensation of deficiencies is advisable to avoid negative postoperative consequences. This study examined the nutritional and protein balance of patients with periprosthetic hip and knee joint infections.

Material and methods. Patients with periprosthetic hip or knee joint infections constituted the study group (SG). Control group I (CG I) included patients with primary implants and CG II included patients who required revision surgery because of aseptic loosening. Relevant nutritional and protein parameters were determined via analysis of peripheral venous blood samples. In addition, a questionnaire was used to evaluate the nutritional and eating patterns of all patients. The nutritional risk screening (NRS) 2002 score and body mass index (BMI) were also calculated for all participants.

Results. Differences were found in the albumin level (SG: $36.23 \pm 7.34$, CG I: $44.37 \pm 3.32$, $p<0.001$, CG II: $44.06 \pm 4.24, p<0.001)$ and total protein in serum (SG: $65.42 \pm 8.66, \mathrm{CG} \mathrm{I:}$ $70.80 \pm 5.33, p=0.004$, CG II: $71.22 \pm 5.21$, $p=0.004)$. The number of patients with lowered albumin levels (SG 19/61, CG I 1/78, CG II 2/55) and total protein in serum (SG: 12/61, CG I 5/78, CG II 2/55) also showed considerable variation. The number of patients with a NRS 2002 score $\geq 3$ differed significantly between SG and both CGs (SG: 5/61, CG I 1/78, CG II 0/55); however, these differences could not be confirmed using BMI.

Conclusion. As expected, lowered albumin and total protein levels were observed in PJ due to the acute phase reaction. The NRS can be performed to exclude nutritional deficiency, which cannot be excluded based on BMI. In cases of periprosthetic joint infection it is reasonable to compensate the nutritional deficiency with dietary supplements.

\section{Keywords}

Vitamin deficiency · Protein deficiency . Malnutrition · Body mass index · Arthroplasty

\section{Bedeutung des Ernährungszustands bei der Entstehung von periprothetischen Infektionen. Eine retrospektive Analyse von 194 Patienten}

\section{Zusammenfassung}

Hintergrund. Unterernährung aufgrund von Protein- und Vitaminmangel ist ein bedeutender negativer Prognosefaktor bei chirurgischen Wundheilungsstörungen und Infektionen. Insbesondere bei elektiven Eingriffen ist ein präoperativer Ausgleich von Mangelerscheinungen ratsam, um negative postoperative Folgen zu vermeiden. Ziel dieser Studie war es, die Ernährungs- und Proteinbilanz von Patienten mit periprothetischen Hüft- und Kniegelenkinfektionen zu untersuchen.

Material und Methoden. Patienten mit periprothetischen Hüft- oder Kniegelenksinfektionen bildeten die Studiengruppe (SG). Die Kontrollgruppe I (CG I) umfasste Patienten mit Primärimplantaten, während die CGII Patienten einschloss, die wegen aseptischer Lockerung eine Revisionsoperation benötigten. Bei allen Patienten wurden relevante
Ernährungs- und Proteinparameter durch die Analyse von Blutproben bestimmt. Darüber hinaus wurde ein Fragebogen zur Bewertung der Ernährungs- und Essgewohnheiten aller Patienten erhoben. Der Score des Nutritional Risk Screening (NRS) 2002 und der BodyMass-Index (BMI) wurden ebenfalls für alle Teilnehmer bestimmt.

Ergebnisse. Unterschiede wurden im Albuminspiegel (SG: $36,23 \pm 7,34$, CG I: $44,37 \pm 3,32 ; p<0,001$; CG II: 44,06 $\pm 4,24$, $p<0,001)$ und im Gesamtprotein im Serum festgestellt (SG: $65,42 \pm 8,66$, CG I:

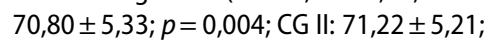
$p=0,004)$. Die Anzahl der Patienten mit erniedrigten Albuminwerten (SG: 19/61, CG I: 1/78, CG II: 2/55) und des Gesamtproteins im Serum (SG: 12/61, CG I: 5/78, CG II: 2/55) zeigten ebenfalls beträchtliche Unterschiede. Die Anzahl der Patienten mit kritischem
Ernährungsstatus (NRS-2002-Score $\geq 3$ ) unterschied sich signifikant zwischen SG und beiden CG (SG: 5/61, CG I: 1/78, CG II: 0/55). Diese Unterschiede konnten jedoch anhand des BMI nicht bestätigt werden. Schlussfolgerung. Wie erwartet, werden aufgrund der Akute-Phase-Reaktion bei periprothetischen Infektionen (PPI) niedrigere Albumin- und Gesamtproteingehalte beobachtet. Mittels NRS kann ein Ernährungsmangel ausgeschlossen werden, dessen Beurteilung aufgrund des BMI nicht sicher möglich ist. Bei Auftreten einer periprothetischen Gelenkinfektion ist es sinnvoll, den Nährstoffmangel durch Nahrungsergänzungsmittel auszugleichen.

Schlüsselwörter Vitaminmangel · Eiweißmangel · Mangelernährung · Body-Mass-Index · Arthroplastik
BMI were also calculated for all study participants [25].

Data were statistically evaluated using Excel 2013 (Microsoft, Redmond, WA, USA) and SPSS v. 24.0 (IBM, Armonk, NY, USA). Data were reviewed for normal distribution using the Shapiro-Wilk test. The non-parametric Mann-Whitney U-test was applied to compare met- ric scaled variables. Nominal and ordinal scaled variables were analyzed using the $\chi^{2}$-test or Fisher's test and $p<0.05$ was considered to be statistically significant. Data were expressed as median and standard deviation (SD).

\section{Results}

- Table 2 presents the characteristics of SG and CGs. A striking significant difference was observed in the NRS 2002 score between SG and CG I (SG: median $=1.0$, $\mathrm{SD}=0.9$; CG I: median $=0.0, \mathrm{SD}=0.7$, $p<0.001)$. A significant difference was also observed in the number of patients 


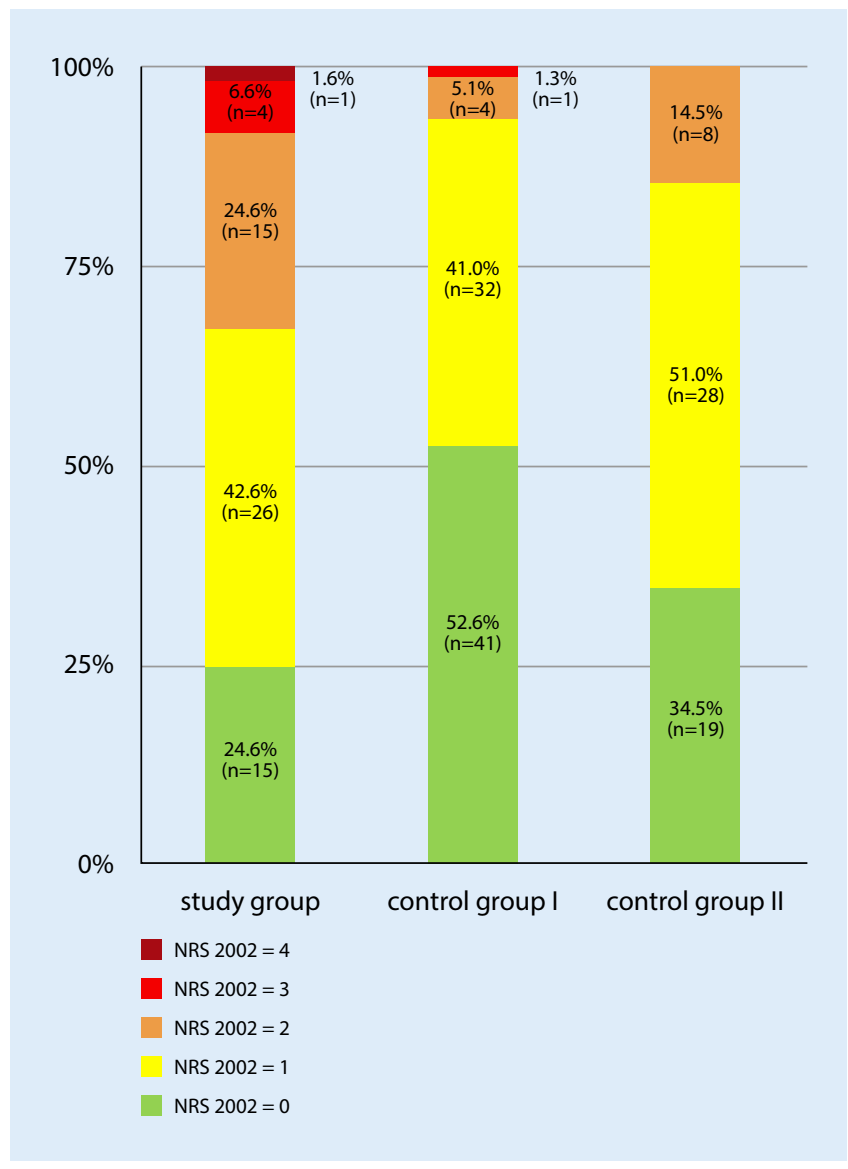

$\mathrm{SD}=5.35 \mathrm{~h}, p=0.003$ and CG II: median $=5.0 \mathrm{~h}, \mathrm{SD}=2.94 \mathrm{~h}, p<0.001)$, i.e., for activities such as shopping or housework. Responses to the individual questions are presented in $\bullet$ Table 4.

\section{Discussion}

The current context of social, economic, and political changes has led to a modification in the eating habits of individuals in industrialized countries and has raised discussions about the impact of these changes. Thus, overnutrition and increasing obesity in particular, pose a serious problem. The proportions of overweight (BMI $\geq 25.0 \mathrm{~kg} / \mathrm{m}^{2}$ ) adult women increased from $22.2 \%(1974-1975)$ to $39.1 \%$ (1989) and 47.0\% (1995-1996), corresponding to an increase of approximately $112 \%$ [25]. In this context, associated metabolic diseases, such as diabetes mellitus and heart diseases, and degenerative joint diseases, such as gonarthrosis and coxarthrosis, have gained in importance [26]. This study also demonstrated an increase in severity of obese nutritional status (BMI $>30 \mathrm{~kg} / \mathrm{m}^{2}$ ) (SG: $41.0 \%$, CG I: $43.6 \%$, and CG II: $45.5 \%)$ in all groups. If patients with a BMI of $>25 \mathrm{~kg} / \mathrm{m}^{2}$ are included, as much as $68.9 \%, 79.5 \%$, and $78.2 \%$ of the patients in SG, CG I, and CG II, respectively, had a pre-obese or obese nutritional status (• Fig. 2).

Clinically relevant vitamin or mineral deficiency is reported to be rare in western countries owing to the low cost and unlimited variety of available foods; however, many people consume enough food that is either unhealthy or of low nutritional value, i.e., food with a lack of proteins, vitamins, minerals, and fiber. In a series of publications, Kaidar-Person et al. reported that the prevalence of symptoms of deficiency of vitamins, proteins, etc. in the morbidly obese population was significantly higher than expected; [13, 14]; therefore, a high BMI with pre-obesity does not completely rule out the possibility of malnutrition. With respect to overweight patients, the survey results also revealed vitamin $\mathrm{D}$ and protein deficiencies in all groups (• Table 3); in particular, patients in the SG exhibited significantly lower protein levels (i.e., albumin level and total protein in serum) 


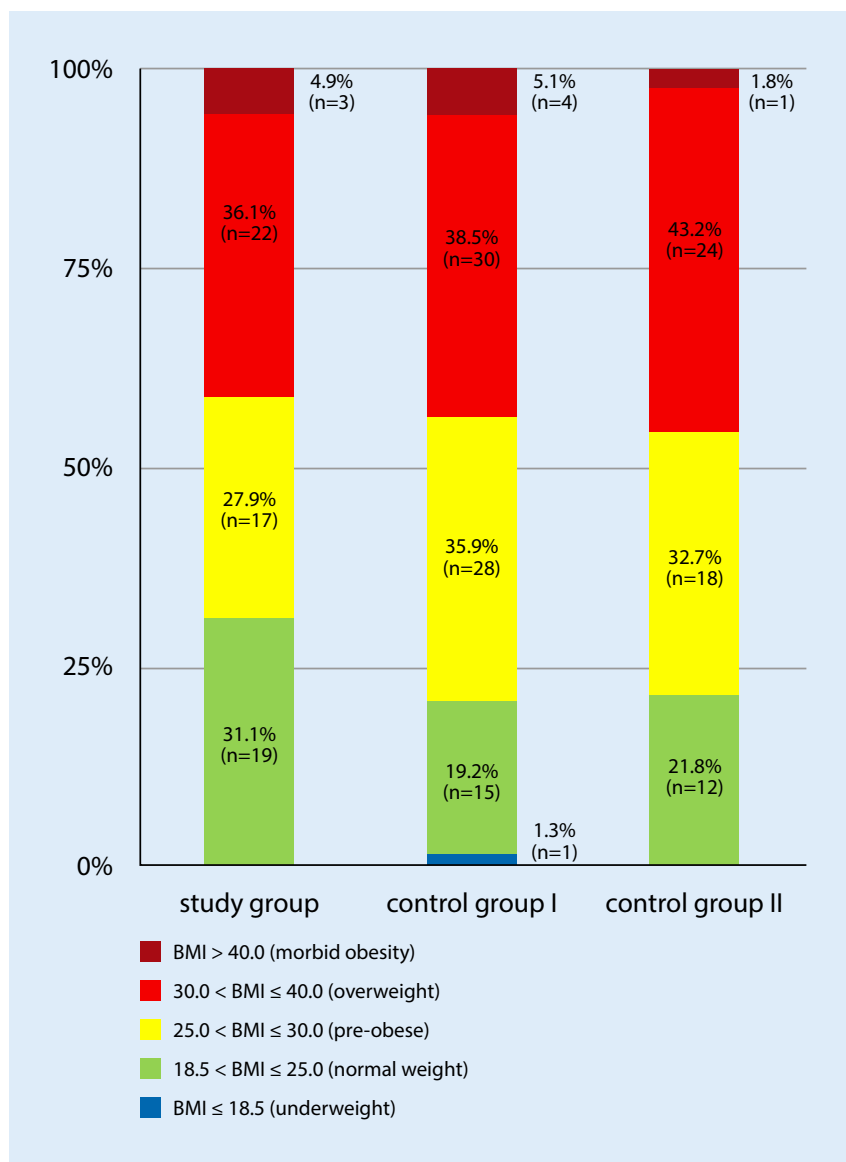

between 2013 and 2015 [33]. The negative influence of associated metabolic diseases, such as diabetes mellitus and circulatory disorders, on the development of PJI has been proven $[34,35]$. Although a high BMI is reportedly associated with higher rates of wound healing disorders and PJI, an altered or decreased BMI is not a useful marker for malnutrition [4].

In the present study, NRS proved to be good predictive factor for PJI. Approximately $75.4 \%$ of the patients in the SG showed conspicuous NRS 2002 scores (NRS 2002 score $\geq 1$ ). The exact distribution within the individual groups is shown in - Fig. 1. Particularly in the field of spinal surgery and arthroplasty, the importance of NRS with respect to wound infections has been demonstrated $[5,27,36]$. A combination of NRS and preoperative analysis of the albumin levels and total protein in serum seems to be essential in this aspect $[9,27]$.

\section{Limitations}

Fig. $2<$ Body mass index $(B M I)$ values in the 3 groups than those in both CGs (- Table 3). This finding can be attributed to the increased consumption during the acute phase reaction and is particularly evident in acute as well as in chronic PJI [27]. Whether a balancing of the proteins, which are consumed in the acute phase reaction is meaningful, cannot be proven based on this study. An isolated substitution of albumin in the course of infection, especially in sepsis, is controversially discussed [28]; however, studies have shown that reduced albumin levels are associated with an increased risk of orthopedic wound infections [29]. A further prospective study is planned for this purpose. Furthermore, optimal blood glucose control should be ensured to assess the effects of overnutrition and metabolic changes, such as prediabetes mellitus. In the present study, compared with those in the CGs a significantly higher number of patients in the SG showed abnormal blood glucose levels (-Table 3 ). It has been proven that an increased level of glycated hemoglobin (HbAlc), in par- ticular, is associated with an increased risk of PJI [30]. Determination and optimization of the level of $\mathrm{HbA} 1 \mathrm{c}$ prior to elective endoprosthesis implantation is also advisable. Although a level of $<7 \%$ is generally recommended, there is no international consensus on the ideal target level of HbAlc; however, in the short term this level can only be achieved to a limited extent in patients with severe diabetes [31,32]. Therefore, optimal postoperative blood glucose control until adequate wound healing seems to be essential to avoid PJI [31].

A tendency with respect to conspicuous BMI could not be confirmed in the individual groups because there were no significant differences among them. In contrast, studies have reported that obesity is one of the most important modifiable patient factors in predicting PJI after THA or TKA; this is evidenced by data from a total of 10,690 and 9481 cases of primary THA and TKA, respectively, retrieved from the New Zealand Surgical Site Infection Improvement Program
Within the scope of this study the consensus meeting criteria for defining PJI were used. This aspect could result in a lower detection of low-grade infections. Therefore, it would be sensible to use a more sensitive classification for future followup studies. A group-specific determination of HbA1c was not performed. In addition, the data are only a snapshot of the levels without a follow-up examination of the patients. For this reason, it is not possible to make statements about the previous nutritional and protein balance of the patients, especially before symptoms of PJI occurred. Therefore, it cannot be said whether they have contributed to the emergence of PJI. Finally, the outcome cannot be assessed according to the study parameters; however, a followup examination of the patients has been planned.

\section{Conclusion}

To predict the risk for periprosthetic infections selected protein levels (e.g., albumin level and total protein in serum) should be preoperatively determined. In addition, NRS can be performed to exclude nutritional deficiencies. In con- 
Table 3 Comparison of the examination groups (SG, CG I primary arthroplasty, CG II aseptic revision) with respect to laboratory evaluations

\begin{tabular}{|c|c|c|c|c|c|c|}
\hline & $\begin{array}{l}\text { Laboratory-specific } \\
\text { standard range }\end{array}$ & SG & CG I & $\begin{array}{l}p \text {-value } \\
\text { (SG vs. CG I) }\end{array}$ & CG II & $\begin{array}{l}p \text {-value } \\
\text { (SG vs. CG II) }\end{array}$ \\
\hline \multicolumn{7}{|l|}{ Laboratory test } \\
\hline Hemoglobin in $\mathrm{mmol} / \mathrm{l}$ & $7.2-10.0$ & $6.16 \pm 2.05$ & $8.56 \pm 0.86$ & $<0.001$ & $8.18 \pm 1.03$ & $<0.001$ \\
\hline Leukocytes in $10^{9} /$ I & $3.5-9.8$ & $8.30 \pm 3.79$ & $7.23 \pm 1.57$ & 0.243 & $7.41 \pm 2.11$ & 0.272 \\
\hline C-reactive protein in $\mathrm{mg} / \mathrm{l}$ & $<5.0$ & $86.21 \pm 98.72$ & $4.55 \pm 1.39$ & $<0.001$ & $13.69 \pm 1.11$ & $<0.001$ \\
\hline Cholesterol in mmol// & $<5.2$ & $4.37 \pm 1.08$ & $5.78 \pm 1.39$ & $<0.001$ & $5.25 \pm 1.11$ & $<0.001$ \\
\hline $\begin{array}{l}\text { High-density lipoprotein (HDL) choles- } \\
\text { terol in } \mathrm{mmol} / \mathrm{l}\end{array}$ & $>1.03$ & $1.04 \pm 0.39$ & $1.62 \pm 0.47$ & $<0.001$ & $1.45 \pm 0.46$ & $<0.001$ \\
\hline $\begin{array}{l}\text { Patients with lowered HDL cholesterol } \\
\text { values in } \% \text { (absolute) }\end{array}$ & $<1.03$ & $54.1(33 / 61)$ & $11.5(9 / 78)$ & n.a. & $23.6(13 / 55)$ & n.a. \\
\hline $\begin{array}{l}\text { Low-density lipoprotein (LDL) choles- } \\
\text { terol in } \mathrm{mmol} / /\end{array}$ & $<4.2$ & $2.65 \pm 0.93$ & $3.64 \pm 1.18$ & $<0.001$ & $3.37 \pm 0.94$ & $<0.001$ \\
\hline $\begin{array}{l}\text { Patients with increased LDL cholesterol } \\
\text { values in } \% \text { (absolute) }\end{array}$ & $>4.2$ & $3.3(2 / 61)$ & $28.2(22 / 78)$ & n.a. & $14.5(8 / 55)$ & n.a. \\
\hline Glucose in mmol/l & n.a. & $7.77 \pm 3.30$ & $6.26 \pm 2.12$ & 0.002 & $6.12 \pm 1.56$ & 0.001 \\
\hline $\begin{array}{l}\text { Noticeable glucose values in \% (abso- } \\
\text { lute) }\end{array}$ & $<7.8$ & $31.1(19 / 61)$ & $12.8(10 / 78)$ & n.a. & $12.7(7 / 55)$ & n.a. \\
\hline Albumin in $\mathrm{g} / \mathrm{l}$ & $35.0-52.0$ & $36.23 \pm 7.34$ & $44.37 \pm 3.32$ & $<0.001$ & $44.06 \pm 4.24$ & $<0.001$ \\
\hline $\begin{array}{l}\text { Patients with lowered albumin values in } \\
\% \text { (absolute) }\end{array}$ & $<35.0$ & $31.1(19 / 61)$ & $1.3(1 / 78)$ & n.a. & $3.6(2 / 55)$ & n.a. \\
\hline Total serum protein in $\mathrm{g} / \mathrm{l}$ & $63.0-83.0$ & $65.42 \pm 8.66$ & $70.80 \pm 5.33$ & 0.004 & $71.22 \pm 5.21$ & 0.004 \\
\hline $\begin{array}{l}\text { Patients with lowered serum protein } \\
\text { values in \% (absolute) }\end{array}$ & $<63.0$ & $19.7(12 / 61)$ & $6.4(5 / 78)$ & n.a. & $3.6(2 / 55)$ & n.a. \\
\hline Creatinine in $\mu \mathrm{mol} / \mathrm{l}$ & $45.0-84.0$ & $83.80 \pm 40.97$ & $93.42 \pm 85.43$ & 0.599 & $75.98 \pm 23.97$ & 0.330 \\
\hline Alanine aminotransferase in $\mu \mathrm{kat} / \mathrm{l}$ & $0.17-0.58$ & $0.34 \pm 0.18$ & $0.41 \pm 0.23$ & 0.074 & $0.37 \pm 0.21$ & 0.514 \\
\hline \multicolumn{7}{|c|}{$\begin{array}{l}\text { Statistically significant values are highlighted in italics } \\
\text { Values are expressed as median ( } \pm \text { mean deviation) or as percentage (absolute/total) } \\
\text { Standard values or the physiological range are given in brackets } \\
\text { SG study group, CGI control group I, CGIl control group II, }\end{array}$} \\
\hline
\end{tabular}

Table 4 Comparison of the examination groups (SG, CG I primary arthroplasty, CG II aseptic revision) with respect to questionnaire evaluation

\begin{tabular}{|c|c|c|c|c|c|}
\hline & SG & CG I & $\begin{array}{l}p \text {-value } \\
\text { (SG vs. CG I) }\end{array}$ & CG II & $\begin{array}{l}\text { p-value } \\
\text { (SG vs. CG II) }\end{array}$ \\
\hline \multicolumn{6}{|l|}{ Questionnaire } \\
\hline $\begin{array}{l}\text { Median time spending outdoors in hours per day } \\
\text { (SD) }\end{array}$ & $1.0(1.15)$ & $2.0(1.45)$ & 0.006 & $2.5(1.41)$ & $<0.001$ \\
\hline $\begin{array}{l}\text { Median time on the move (shopping, housework) in } \\
\text { hours per day (SD) }\end{array}$ & $2.0(2.61)$ & $3.0(5.35)$ & 0.003 & $5.0(2.94)$ & $<0.001$ \\
\hline Sports activities in \% (absolute) & $19.7(12 / 61)$ & $30.8(24 / 78)$ & 0.138 & $38.2(21 / 54)$ & 0.023 \\
\hline Median sports activities in hours per week (SD) & $3.5(2.88)$ & $2.5(4.36)$ & 0.149 & $3.0(2.96)$ & 0.484 \\
\hline $\begin{array}{l}\text { Unintentional weight loss in the last } 1-3 \text { months in \% } \\
\text { (absolute) }\end{array}$ & $11.5(7 / 61)$ & $3.8(3 / 77)$ & 0.088 & $12.7(7 / 55)$ & 0.836 \\
\hline $\begin{array}{l}\text { Lower food intake in the last few weeks in \% (abso- } \\
\text { lute) }\end{array}$ & $31.1(19 / 61)$ & $12.8(10 / 78)$ & 0.008 & $20.0(11 / 54)$ & 0.189 \\
\hline \multicolumn{6}{|c|}{$\begin{array}{l}\text { Statistically significant values are highlighted in italics } \\
\text { The values are expressed as median ( } \pm \text { mean deviation) or as percentage (absolute/total) } \\
\text { The standard values or the physiological range are given in brackets } \\
\text { SD standard deviation, SG study group, CGI control group I, CGII control group II }\end{array}$} \\
\hline
\end{tabular}




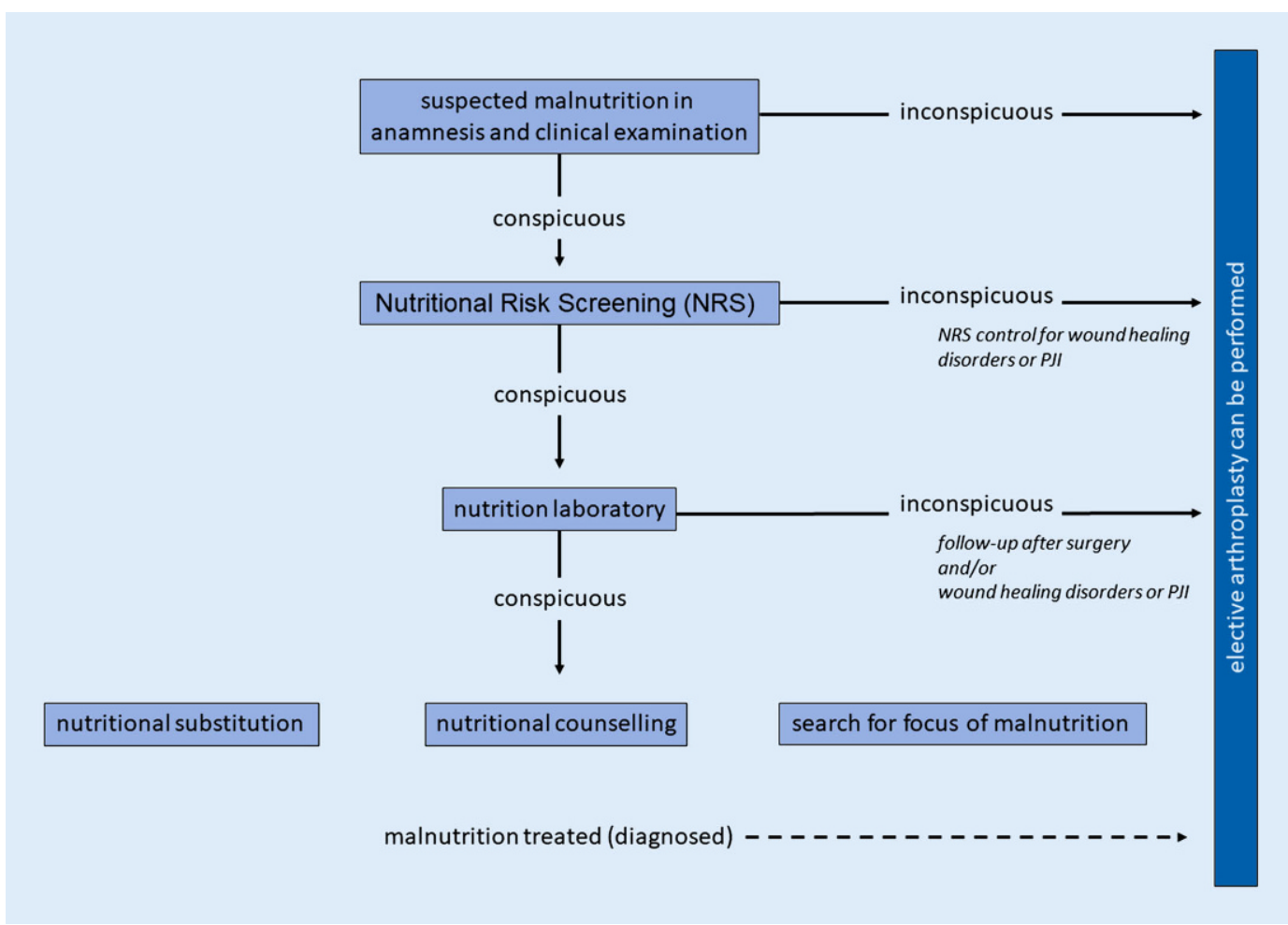

Fig. $3<$ Diagnostic algorithm for assessing the nutritional status before elective arthroplasty

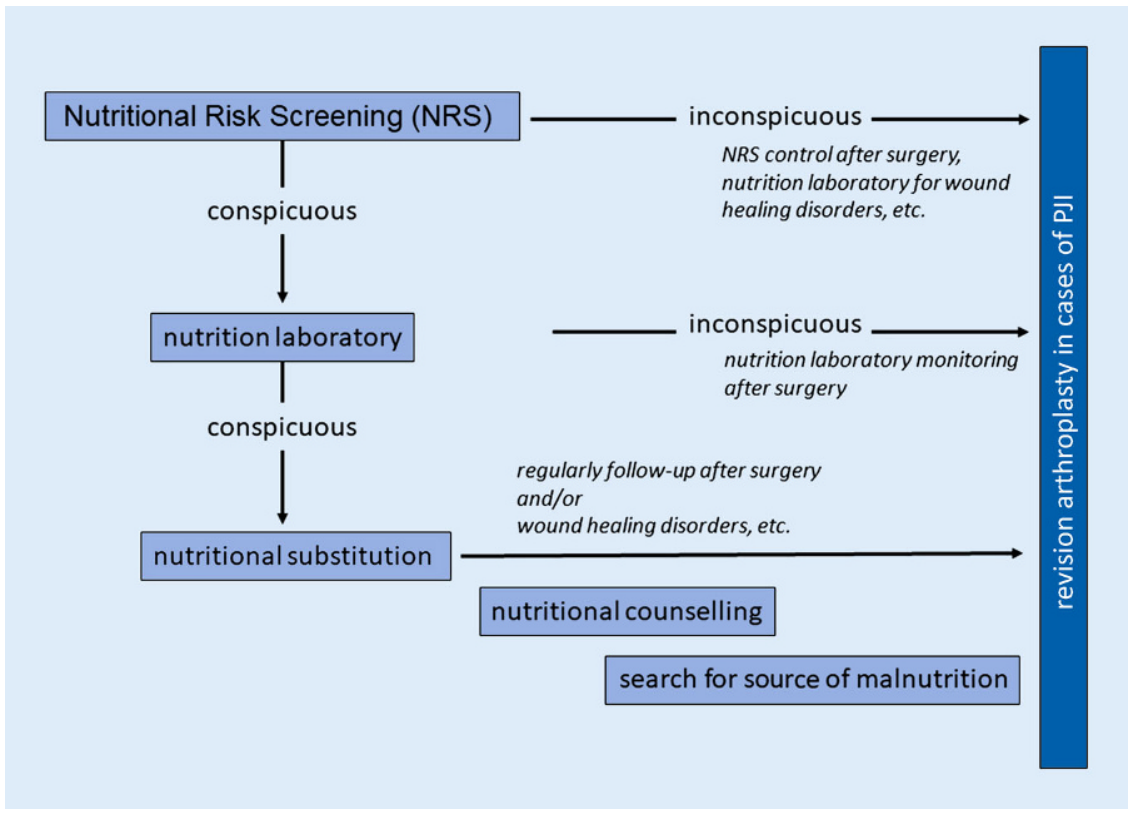

Fig. $4 \Delta$ Diagnostic algorithm for assessing the nutritional status of periprosthetic joint infection (PJI)

trast, BMI is not suitable for assessing nutritional deficiency because malnutrition can also be present in a pre-obese nutritional condition. In the case of an existing PJI, compensation for the nutritional deficiency with dietary supplements is recommended, particularly for protein and vitamin deficiencies. An algorithm for dealing with malnutrition in

\section{Corresponding address}

\section{PD Dr. Dirk Zajonz}

Clinic for Orthopaedics, Traumatology and Reconstructive Surgery, Zeisigwald Hospitals BETHANIEN Chemnitz Zeisigwaldstraße 101, 09130 Chemnitz, Germany dirk.zajonz@ediacon.de

Acknowledgements. The authors acknowledge the support of the nonprofit German Arthritis Society (Deutsche Arthrose-Hilfe e. V.) and its president Helmut H. Huberti, MD (grant number, P339). The authors also recognize the support of the German Research Foundation (DFG) and the University Hospital Leipzig within the program of open access publishing. We thank the personnel of the Institute of Laboratory Medicine, Clinical Chemistry and Molecular Diagnostics, University of Leipzig for their support in the evaluation of the laboratory values.

Funding. This study was funded by the nonprofit German Arthritis Society (Deutsche Arthrose-Hilfe e. V.), the German Research Foundation (DFG), and the University Hospital of Leipzig within the program of Open Access Publishing. The funding body had no impact on the design of the study; the collection, analysis, and interpretation of the data; or in the writing of the manuscript.

Author Contribution. DZ analyzed and interpreted all patient data and was a major contributor to writing the manuscript. FP and AD collected the data and significantly contributed to the preparation of the manuscript. ME and RM were responsible for translation and jointly performed the statistical analyses. JK performed the chemical laboratory tests. $D Z$, JKMF, MG, CJ, and AR were mainly responsible for 
the patient treatment and contributed as assistants to the preparation of the work. All authors read and approved the final manuscript.

Funding. Open Access funding provided by Projekt DEAL.

\section{Compliance with ethical guidelines}

Conflict of interest. D. Zajonz, A. Daikos, F. Prager, M. Edel, R. Möbius, J.K. M. Fakler, A. Roth and M. Ghanem declare that they have no competing interests.

Ethical standards. The ethics committee of the University Hospital of Leipzig, Germany granted approval of this study (approval number 025-16-01022016). The committee is listed on the Institutional Review Board of the Office for Human Research Protections (OHRP) IORG0001320, IRB00001750. All procedures performed in studies involving human participants or on human tissue were in accordance with the ethical standards of the institutional and/or national research committee and with the 1975 Helsinki declaration and its later amendments or comparable ethical standards. Prior to study initiation, all patients provided written informed consent for the treatment contract, study, and publication of the anonymized data.

Open Access. This article is licensed under a Creative Commons Attribution 4.0 International License, which permits use, sharing, adaptation, distribution and reproduction in any medium or format, as long as you give appropriate credit to the original author(s) and the source, provide a link to the Creative Commons licence, and indicate if changes were made. The images or other third party material in this article are included in the article's Creative Commons licence, unless indicated otherwise in a credit line to the material. If material is not included in the article's Creative Commons licence and your intended use is not permitted by statutory regulation or exceeds the permitted use, you will need to obtain permission directly from the copyright holder. To view a copy of this licence, visit http://creativecommons.org/licenses/by/4.0/.

\section{References}

1. Adeli B, Parvizi J (2012) Strategies for the prevention of periprosthetic joint infection. J Bone Joint Surg Br 94(11 Suppl A):42-46. https://doi. org/10.1302/0301-620X.94B11.30833

2. Boettner F, Cross MB, Nam D et al (2011) Functiona and emotional results differ after aseptic vs septic revision hip Arthroplasty. HSS J 7(3):235-238. https://doi.org/10.1007/s11420-011-9211-6

3. Hanssen AD, Osmon DR, Nelson CL (1997) Prevention of deep periprosthetic joint infection. Instr Course Lect 46:555-567

4. Zajonz D, Brand A, Lycke C et al (2018) Risk factors for early infection following hemiarthroplasty in elderly patients with a femoral neck fracture. Eur J Trauma Emerg Surg. https://doi.org/10.1007/ s00068-018-0909-8

5. Cross MB, Yi PH, Thomas CF et al (2014) Evaluation of malnutrition in orthopaedic surgery. J Am Acad Orthop Surg 22(3):193-199. https://doi.org/10. 5435/JAAOS-22-03-193

6. Font-Vizcarra L, Lozano L, Ríos J et al (2011) Preoperative nutritional status and post-operative infection in total knee replacements: a prospective study of 213 patients. Int J Artif Organs 34(9):876-881. https://doi.org/10.5301/ijao. 5000025

7. Del Savio GC, Zelicof SB, Wexler LM et al (1996) Preoperative nutritional status and outcome of elective total hip replacement. Clin Orthop Relat Res 326:153-161

8. Gherini S, Vaughn BK, Lombardi AV et al (1993) Delayed wound healing and nutritional deficiencies after total hip arthroplasty. Clin Orthop Relat Res 293:188-195

9. Greene KA, Wilde AH, Stulberg BN (1991) Preoperative nutritional status of total joint patients. Relationship to postoperative wound complication. J Arthroplasty 6(4):321-325

10. Huang R, Greenky M, Kerr GJ et al (2013) The effect of malnutrition on patients undergoing elective joint arthroplasty. J Arthroplasty 28(8 Suppl):21-24. https://doi.org/10.1016/j.arth. 2013.05.038

11. Ong KL, Kurtz SM, Lau E et al (2009) Prosthetic joint infection risk after total hip arthroplasty in the Medicare population. J Arthroplasty 24(6 Suppl):105-109. https://doi.org/10.1016/j.arth. 2009.04.027

12. Jensen JE, Smith TK, Jensen TG et al (1981) The Frank Stinchfield Award Paper. Nutritional assessment of orthopaedic patients undergoing total hip replacement surgery. Hip 1981:123-135

13. Kaidar-Person O, Person B, Szomstein S et al (2008) Nutritional deficiencies in morbidly obese patients: a new form of malnutrition? Part A: vitamins. OBES SURG 18(7):870-876. https://doi. org/10.1007/s11695-007-9349-y

14. Kaidar-Person O, Person B, Szomstein S et al (2008) Nutritional deficiencies in morbidly obese patients: A new form of malnutrition? Part B: minerals. OBES SURG 18(8):1028-1034. https:// doi.org/10.1007/s11695-007-9350-5

15. Bohl DD, Shen MR, Kayupov E et al (2016) Is Hypoalbuminemia associated with septic failure and acute infection after revision total joint Arthroplasty? A study of 4517 patients from the national surgical quality improvement program. J Arthroplasty 31(5):963-967. https://doi.org/10 1016/j.arth.2015.11.025

16. Kamath AF, Nelson CL, Elkassabany $\mathrm{N}$ et al (2017) Low albumin is a risk factor for complications after revision total knee Arthroplasty. J Knee Surg 30(3):269-275. https://doi.org/10.1055/s-00361584575

17. Abhimanyu CAK (2017) The role of UV radiation and vitamin D in the seasonality and outcomes of infectious disease. Photochem Photobiol Sci 16(3):314-338. https://doi.org/10.1039/ c6pp00355a

18. Hegde V, Dworsky EM, Stavrakis Al et al (2017) Single-dose, preoperative vitamin-D supplementation decreases infection in a mouse model of Periprosthetic joint infection. JBone Joint Surg Am 99(20):1737-1744. https://doi.org/10.2106/JBJS 16.01598

19. Maier GS, Horas K, Seeger JB et al (2014) Is there an association between periprosthetic joint infection and low vitamin D levels? Int Orthop 38(7):1499-1504. https://doi.org/10. 1007/s00264-014-2338-6

20. Signori V, Romanò CL, de Vecchi E et al (2015) May osteoarticular infections be influenced by vitamin D status? An observational study on selected patients. BMC Musculoskelet Disord 16:183. https://doi.org/10.1186/s12891-015-0648-5

21. Cranney A, Horsley T, O'Donnell S et al (2007) Effectiveness and safety of vitamin D in relation to bone health. Evid Rep Technol Assess 158:1-235
22. Feindt E, Ströder J (1977) Zur antimikrobiellen Wirkung von Vitamin D (Studies on the antimicrobial effect of vitamin D (author's transl)). Klin Wochenschr 55(10):507-508

23. Fayaz HC, Jupiter JB (2017) The zeitgeist of challenging the evidence. A perspective on the international consensus meeting on Periprosthetic joint infection. Arch Bone Jt Surg 5(1):32-38

24. Honkanen $M$, Jämsen $E$, Karppelin M et al (2017) Concordance between the old and new diagnostic criteria for periprosthetic joint infection. Infection 45(5):637-643. https://doi.org/10.1007/s15010017-1038-8

25. Souza NPd, Lira PICd, Fontbonne A et al (2017) A (des)nutrição e o novo padrão epidemiológico em um contexto de desenvolvimento e desigualdade ((Mal)nutrition and the new epidemiological trend in a context of development and inequalities). Cien Saude Colet 22(7):2257-2266. https://doi.org/10. 1590/1413-81232017227.03042017

26. Shin D, Kongpakpaisarn K, Bohra C (2018) Trends in the prevalence of metabolic syndrome and its components in the United States 2007-2014. Int J Cardiol 259:216-219. https://doi.org/10.1016/j. ijcard.2018.01.139

27. YiPH, Frank RM, Vann E et al (2015) Is potential malnutrition associated with septic failure and acute infection after revision total joint arthroplasty? Clin Orthop Relat Res 473(1):175-182. https://doi. org/10.1007/s11999-014-3685-8

28. Vincent J-L, Russell JA, JacobMet al (2014) Albumin administration in the acutely ill: what is new and where next? Crit Care 18(4):231. https://doi.org/ $10.1186 /$ cc13991

29. Yuwen P, Chen W, Lv H et al (2017) Albumin and surgical site infection risk in orthopaedics: a metaanalysis. BMC Surg 17(1):7. https://doi.org/10. 1186/s12893-016-0186-6

30. Shohat N, Muhsen K, Gilat R et al (2018) Inadequate Glycemic control is associated with increased surgical site infection in total joint Arthroplasty: a systematic review and metaanalysis. J Arthroplasty. https://doi.org/10.1016/j. arth.2018.02.020

31. Adams AL, Paxton EW, Wang JQ etal (2013) Surgical outcomes of total knee replacement according to diabetes status and glycemic control, 2001 to 2009 J Bone Joint Surg Am 95(6):481-487. https://doi. org/10.2106/JBJS.L.00109

32. Giori NJ, Ellerbe LS, Bowe T et al (2014) Many diabetic total joint arthroplasty candidates are unable to achieve a preoperative hemoglobin A1c goal of $7 \%$ or less. J Bone Joint Surg Am 96(6):500-504. https://doi.org/10.2106/JBJS.L. 01631

33. Jung P, Morris AJ, Zhu M et al (2017) BMI is a key risk factor for early periprosthetic joint infection following total hip and knee arthroplasty. N Z Med J130(1461):24-34

34. Cunningham DJ, Kavolus JJ, Bolognesi MP et al (2017) Common medical Comorbidities correlated with poor outcomes in hip Periprosthetic infection. J Arthroplasty 32(9S):S241-S245.e3. https://doi. org/10.1016/j.arth.2017.03.037

35. Shohat N, Goswami K, Tarabichi M et al (2018) All patients should be screened for diabetes before total joint Arthroplasty. J Arthroplasty. https://doi org/10.1016/j.arth.2018.02.047

36. Rai J, Gill SS, Kumar BRJS (2002) The influence of preoperative nutritional status in wound healing after replacement arthroplasty. Orthopedics 25(4):417-421 
Hier steht eine Anzeige.

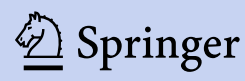

